насамперед це інші проєкти, створені на основі пропозицій Й. Їречека, та розробки Івана Лучука, Сергія Мельника, Максима Лагоди. Проте жодна 3 них до сьогодні не замінила кириличного алфавіту в Україні, а латиниця використовується для інших функцій, насамперед для транслітерації, моделювання образності, атракційності художнього та публіцистичного тексту (дискурсу) та ін., що потребує докладного опису.

\title{
Література:
}

1. Історія української мови: словник-довідник / ідея, упорядкування та окремі статті В. В. Денисюка. Умань. Візаві. 2013. 387 с.

2. Космеда Т. А. Комунікативна компетенція Івана Франка: міжкультурні, інтерперсональні, риторичні виміри: монографія. Львів. ПАІС. 2006. 328 с.

3. Українська мова : енциклопедія / редкол.: В. М. Русанівський та ін.; НАН України, Ін-т мовознав. ім. О. О. Потебні, Ін-т укр. мови. Київ. Вид-во "Українська енциклопедія" ім. М. П. Бажана. 2004. 820 с.

4. Франко I. Азбучна війна в Галичині 1859 р., Франко І. Твори в 50 томах. Київ. Наукова думка. 1986. Т. 47. С. 549-650.

5. Шашкевич М. Азбука і абецадло. Письменники Західної України 30-50-х років ХІХ ст. Київ. Наукова думка. 1965. С.113-120.

DOI https://doi.org/10.30525/978-9934-26-110-7-8

\section{АВТОПОБАЖАЛЬНІ КОНСТРУКЦЇ̈ В СУЧАСНІЙ УКРАЇНСЬКІЙ МОВІ}

\author{
Умрихіна Л. В. \\ кандидат філологічних наук, \\ доцент кафедри украӥнознавства і лінгводидактики \\ Харківський національний педагогічний університет \\ імені Г. С. Сковороди \\ м. Харків, Україна
}

Автопобажальні конструкції представлені конструкціями структурних схем $\quad \mathrm{N}_{1} \mathrm{Vf}_{\text {des } 1 \mathrm{sg} / \mathrm{p} l}, \quad \mathrm{~N}_{1} \mathrm{Vf}_{\text {des } 1} \mathrm{~N}_{1 / 5}, \quad \mathrm{~N}_{1} \mathrm{Vf}_{\text {deslsg/pl(cop) }} \mathrm{Adj}_{1 / 5}$, $\mathrm{N}_{1} \mathrm{Vf}_{\text {des1 } 1 \mathrm{sg} / \mathrm{pl}(\mathrm{cop})}$ Part $_{1 / 5}, \mathrm{~N}_{1} \mathrm{Vf}_{\text {des } 1 \mathrm{sg}(\mathrm{cop})} \mathrm{N}_{2,3 \ldots}$.

Автопобажальні конструкції структурної схеми $\mathrm{N}_{1} \mathrm{Vf}_{\text {des1sg/pl }} \epsilon$ граматичною реалізацією вихідної конструкції структурної схеми $\mathrm{N}_{1} \mathrm{Vf}$ у формі синтаксичного ірреального способу, організованого через 
видозміну дієвідмінюваного дієслова - присудка - у форму теперішнього/ майбутнього часу + (не)хай. Підмет виражений займенником я. Його позиція може бути незаміщена, що зумовлено граматичною повноцінністю дієслівної форми щодо означення семантичного суб'єкта.

Помітною є рідковживаність таких конструкцій у бажальному значенні, як і в спонукальному. Спонукальні конструкції із присудком, вираженим дієсловом у формі першої особи однини наказового способу, $\epsilon$ оказіональним мовним утворенням. Це автоспонукальні конструкції, які виражають спонукання до дії, потенційним виконавцем якої є сам мовець. Для такого формально-синтаксичного типу конструкцій, агенсом у яких є перша особа, спонукання, взагалі, не притаманне. Ситуація, за якої мовець просить адресата бути посередником у спонуканні самого мовця, є не зовсім природною. Семантика таких конструкцій тяжіє до сфери бажальності, яка суперечить вияву активної діяльності людини на шляху до здійснення чогось.

Неоднозначна семантика відповідної дієслівної форми зумовлює контроверсійність віднесення ії до грамем наказового способу. Донедавна iї розглядали у складі шестичленної способової парадигми, указуючи на периферійний характер: «Аналітичні форми першої особи однини наказового способу здатні репрезентувати категорію спонукальності, хоча й посідають найвіддаленіше місце від центру в особовій парадигмі наказового способу і кваліфікуються як форми 3 найслабкішою спонукальністю» [1, с. 66]. Новітне бачення способової парадигми позначене обережністю щодо кваліфікації аналізованої форми. Автори [2] вказують на існування в мовознавстві традиційного погляду на проблему, відповідно до якого способова парадигма $\epsilon$ п'ятичленною, що із неї вилучена згадана грамема, згадуючи про відомі міркування щодо віднесення iї до наказового способу. Тож аналізовану дієслівну форму правомірно вважати більше виразником бажального значення, ніж спонукального.

Конструкції структурної схеми $\mathrm{N}_{1} \mathrm{Vf}_{\text {des } 1 \mathrm{sg} / \mathrm{pl}} \in$ автореферентними, оскільки бажана ситуація в них орієнтована на виконання самим суб'єктом бажання. Вони виражають бажану активну або статичну / ментальну дію: Матусенько, ріднесенька, рибочко, голубочко, перепілочко! Не зопиняй же мене. Я ж собі ще молода; нехай же я погуляю, як та птичка на волі під небесами літає (Г. КвіткаОснов'яненко); Но серие моє замирає, начувається для себе великого горя. Братику Миколо, ти говорив мені, що ти їх родич, чи не можна тобі довідаться о сватанні Наталки? Нехай буду знати свою долю 
(І. Котляревський); Господи! < ... Нехай я живу так, щцоб у тобі зійти на небо. Амінь (М. Ярема);

- Хай живе перемога! I мир!

- Хай живемо ми!

- Хай живу трохи і я, Іван Орлюк, сержант (О. Довженко).

Автопобажальні конструкції структурних схем $\mathrm{N}_{1} \mathrm{Vf}_{\text {des } 1} \mathrm{~N}_{1 / 5}$, $\mathrm{N}_{1} \mathrm{Vf}_{\text {des } 1 \mathrm{sg} / \mathrm{pl}(\mathrm{cop})} \mathrm{Adj}_{1 / 5}, \quad \mathrm{~N}_{1} \mathrm{Vf}_{\text {des } 1 \mathrm{sg} / \mathrm{pl} \text { (cop) }} \quad$ Part $_{1 / 5}, \quad \mathrm{~N}_{1} \mathrm{Vf}_{\text {des } 1 \mathrm{sg}(\text { (cop })} \mathrm{N}_{2,3 \ldots} \quad \epsilon$ граматичною реалізацією вихідної конструкції структурної схеми $\mathrm{N}_{1} \mathrm{Vf}$ у формі синтаксичного ірреального способу, організованого через видозміну дієвідмінюваного службового дієслова - структурного компонента складеного присудка - у форму теперішнього/ майбутнього часу $+($ не) $x a и ̆$. Підмет виражений займенником я. Це конструкції 3 іменним складеним присудком, компонентами якого є службове слово $\mathrm{i}$ предикативне ім'я. За іменну частину правлять форми іменників, прикметників, прислівників, дієприкметників у називному або орудному відмінку. Оформлення складеного присудка відбувається аналогічно 3 автопобажальними конструкціями структурних схем $\mathrm{N}_{1} \mathrm{Vf}_{\text {des3sg/pl(cop) }} A d j$, $\mathrm{N}_{1} \mathrm{Vf}_{\text {des3sg/pl(cop) }}$ Part, $\mathrm{N}_{1} \mathrm{Vf}_{\text {des33g(cop) }} \mathrm{N}_{2,3 \ldots}, \mathrm{N}_{1} \mathrm{Vf}_{\text {des33g/pl }} \mathrm{N}_{1}$. Позиція підмета часто незаміщена, що зумовлено граматичною достатністю дієслівної форми в плані означення семантичного суб'єкта.

Автопобажальні конструкції структурних схем $\mathrm{N}_{1} \mathrm{Vf}_{\text {des } 1} \mathrm{~N}_{1 / 5}$, $\mathrm{N}_{1} \mathrm{Vf}_{\text {des1sg/pl(cop) }} \mathrm{Adj}_{1 / 5}, \quad \mathrm{~N}_{1} \mathrm{Vf}_{\text {des } 1 \mathrm{sg} / \mathrm{pl}(\mathrm{cop})} \mathrm{Part}_{1 / 5}, \quad \mathrm{~N}_{1} \mathrm{Vf}_{\text {des } 1 \mathrm{sg}(\text { (cop })} \mathrm{N}_{2,3 \ldots}$ виражають бажану ознаку суб'єкта мовлення, що органічніше інтегрується в зміст бажального значення, ніж бажана дія. Бажальний сенс здебільшого отримує непідвладна людській волі ситуація, ніж та, якою він може керувати, активно діючи. Тому такі конструкції $\epsilon$ звичними для сприйняття й традиційного уявлення про автопобажання.

Автопобажальні конструкції структурної схеми $\mathrm{N}_{1} \mathrm{Vf}_{\text {des } 1} \mathrm{~N}_{1 / 5}$ виражають бажану постійну ознаку чи якісну характеристику семантичного суб'єкта - суб'єкта мовлення: - Ти видів, брате, таке лицемірство? Хай буду песій син, якщо то щиро! (В. Малик); Нехай я стану злидарем в чужсім краю (М. Лукаш).

Автопобажальні конструкції структурної схеми $\mathrm{N}_{1} \mathrm{Vf}_{\text {desisg/pl(cop) }} \mathrm{Adj}$ виражають бажану якісну характеристику семантичного суб'єкта суб'єкта мовлення: А Наталка благала: Тату! Нехай я буду щасливою! Може ж, я буду щасливою!.. - I враз рішуче, з докором, хоч і крізь сльози: - Я не переступила вашої волі, в мене ваме серие, ви його мені дали таке, - то й хай же Бог буде суддею <...> Але нехай ми будем щцасливі, тату! (І. Багряний). 
Автопобажальні конструкції структурної схеми $\mathrm{N}_{1} \mathrm{Vf}_{\text {deslsg/pl(cop) }}$ Part $_{1 / 5}$ виражають бажану якісну характеристику семантичного суб'єкта суб'єкта мовлення: Нехай я буду з Тобою розп'ятий, а не спасаю своє життя для себе самого (М. Ярема).

Автопобажальні конструкції структурної схеми $\mathrm{N}_{1} \mathrm{Vf}_{\text {des1sg(cop) }} \mathrm{N}_{2,3 \ldots}$ виражають бажану непостійну ознаку (рід діяльності, стан, локалізацію тощо) семантичного суб'єкта - суб'єкта мовлення: Не держіть мене як дочку, нехай я буду вам замість наньмички: усяку роботу, що скажете, буду робити і не охну. (Г. Квітка-Основ'яненко).

\section{Література:}

1. Городенська К. Г. Семантична структура імператива. Актуальні проблеми граматики : зб. наук. пр. Кіровоград: Кіровоградський педагогічний інститут ім. В. К. Винниченка, 1996. Вип. 1. С. 63-68.

2. Граматика сучасної української мови. Морфологія / Вихованець I. Р., Городенська К. Г., Загнітко А. П., Соколова О. С. К.: Видавничий дім Дмитра Бураго, 2017. 752 с.

DOI https://doi.org/10.30525/978-9934-26-110-7-9

\section{РЕПРЕЗЕНТАЦІЯ АНТРОПОНІМІВ У ПАМ'ЯТКАХ ДАВНЬОЇ ЛЕКСИКОГРАФІЇ}

\section{Чорноус О. В.}

кандидат філологічних наук, доцент, завідувач кафедри загальної підготовки та сочіальної роботи Кропивницький інститут державного та муніџипального управління м. Кропивницький, Україна

На сьогодні питання про те, коли саме 3'явилися перші праці, об'єктом студіювання яких були антропоніми, не отримало однозначної відповіді. Утім відомо, що вже в античності філософи сперечалися щодо походження пропріативів загалом та власних назв людей зокрема. Деякі їхні висновки були підтверджені кількома століттями пізніше в результаті вже наукового вивчення онімів: наприклад, Аристотелем було спостережено здатність власних назв позначати одиничні, унікальні об'єкти, яке він проілюстрував твердженням «Сонце - дещо одиничне, подібно до Клеона чи Сократа» [2, с. 219]. 